\title{
Positive Assessment as Support to Personal Life Designing in Transition to Adulthood: A Case Study
}

\author{
Teresa Maria Sgaramella*, Margherita Bortoluzzi and Federica Carollo \\ FISPPA Department University of Padova (Italy), Pedagogy and Applied Psychology, Italy
}

Submission: March 25, 2019; Published: June 26, 2019

*Corresponding author: Teresa Maria Sgaramella, FISPPA Department University of Padova (Italy), Via Venezia 14, 35131 Padova, Italy

\begin{abstract}
Transitioning to adulthood is a natural process involving multiple factors. Adolescents living with developmental disabilities experience more difficulties in anticipating and dealing with transitions, in moving toward positive adulthood trajectories. According to current counseling literature some resources are particularly relevant in order to support these goals.

The case study presented here is an example of the possibility and usefulness of giving voice to adolescents with developmental disability who are close to life transitions and assessing their resilience, adaptability, courage and future goals.

Professionals interested in social and work inclusion of young adults with developmental disabilities are then invited to highlight relevant attitudes toward everyday life and resources for future life designing

Keywords: Positive assessment; Adolescents; Resilience; Adaptability; Trajectories
\end{abstract}

\section{Introduction}

Transitioning to adulthood is a natural process involving multiple factors. In current times adolescents are required and will increasingly be required to refer to and foster their strengths and courage in order to reach and maintain social and work inclusion goals [1,2]. They need then support in becoming experts in anticipating and dealing with transitions, in developing resources in order to manage frequent work and life transitions [3]. Although limited in number, research findings involving adolescents experiencing chronic and disabling health conditions clearly evidence the relevance of describing these resources because of the possible role they may play on positive adulthood trajectories. According to current lliterature some resources as particularly relevant in order to address these goals.

\section{Resilience}

It is one of the most relevant resources to life designing in complex life conditions [4]. A relationship has been, in fact, described between resilience, career optimism, wellbeing, and academic achievement in emerging adults with disability [5]. more commitment with educational and work goals has been shown in resilient students with ADHD and with psychiatric disabilities [6]. as well as influence on job satisfaction [7].

\section{Adaptability resources}

Resources commonly grouped under this heading (namely curiosity, confidence, concern, control and cooperation) are relevant in handling developmental tasks adolescents go through for a full participation in community life and to prepare for future roles [8]. Studies involving individuals with disabilities frequently evidence limited future planning [9]. limited involvement in job experiences and in training that allow them to develop skills and to adapt to changes [10]. lower selfeveficay than non-disabled peers in career decision making [11] due to more frequent barriers and lower support. Confidence experienced in the possibility of being actively involved in work strongly influence future employment outcomes in adolescents and young adults with intellectual or developmental disabilities [12]. On the other hand, actions tailored to these resources increase their awareness about their strengths and weaknesses, reduce difficuties in identifying career goals and facilitate future 
planning and life designing [13].

These studies support the relevance of addressing resilience and adaptability in the assessment procedures involving adolescents with intellectual and developmental disabilities. They also underline the relevance to embrace an integrated, strengths-based model of assessment and systematically introduce an analysis of these resources in counselling with adolescents experiencing developmental disabilities $[14,15]$.

The case study presented here is an example of the possibility and usefulness of giving voice to adolescents with intellectual disability who are close to life transitions and assess their resilience, adaptability, courage and future goals, thus collecting relevant information about attitudes toward everyday life experience and resources for future life designing

\section{Case Study}

Chiara (this is the name she proposed for herself when informed and asked consent to share her story in our research and didactic activities) described herself with the following words "I am 18 y.o. girl and I was born in Veneto. I have a sister who lives and studies in Trentino. My mom has some small health problem. I have a small disability, a gloomy spastic paresis. For my eye problems I discovered the use of technology and its importance. I attend high school and my favourite subjects are Greek and Latin. I love studying. My hobbies are theatre and swimming pool, which I attend weekly. Once a week I also attend the "Golden Farm" where I am in contact with nature. My favourite hobbies are listening to music and doing chores. I 'm close to leave high school and I have some decisions to take".

\section{Notes from Chiara's basic functional assessment}

Chiara was diagnosed a mild to moderate developmental disability because of her sensory and motor difficulties. Her executive functioning at the time of counseling was assessed using the Frontal Assessment Battery [16]. Chiara obtained a total score of 5/15 in the 5 tasks she could perform, showing basic knowledge as regards semantic association and verbal fluency, and some flexibility in alternating sequences. Visual supports compensated for her sensory difficulties and helped her reading, studying and memorizing complex concepts. After interviewing a family member and an educator using VALIAB, a questionnaire addressing behavioral independence and autonomy levels in 7 everyday life domains [17] several strengths emerged concerning moderate to high orientation and tolerance towards variations in the environment; persistent commitment in activities proposed by the context and ability to communicate with people.

\section{Material and Methods}

The analysis was focused on resilience, adaptability resources, courage and future goals.

To analyse resilience and future time perspective we used the Design My Future questionnaire [18]. The instrument consists of 21 items assessing resilience (e.g., "I think I'm able to challenge the difficult situations that may arise in the future for me") and future orientation (e.g., "Look ahead and think about what will happen in the future makes me feel full of energy"). Participants responded to each item on a scale from 1 (not strong) to 5 (strongest).

Adaptability resources were analysed using the extended version of the Career Adaptability Scale [19] measuring concern, control, curiosity, confidence and cooperation. Items are rated on a 5-point Likert-type scale ranging from 5 (strongest) to 1 (weakest). Higher scores reflect greater psychosocial resources.

Qualitative procedures were used to collect Chiara's view on courage and future goals. Courage was analysed with a modified version of Korner's interview [2]. Chiara was asked to tell stories of courage she experienced in her past and current life but also actions she expected would require her courage in her future. As regards future goals, she was asked to list main goals she had in mind when thinking to her future in different life domains, with a particular attention to work.

Supports and personalization were used for the assessment. Large pictorial representations of the alternatives were made available to support her answering the questionnaires. However, to ensure active participation and understanding, the most used and effective strategy was after each statement repeating the alternatives among which she could choose the answers. This increased and maintained high her attention and accuracy in the responses she provided.

The analysis of positive attitudes and resources was based on normalization of the raw scores in t-scores. In developing her profile, a clinical criterion was introduced: a t-score inferior to 40 was considered as an index of an emerging level of resources or attitudes hence suggesting a vulnerability in the specific dimension; a t-score ranging from 40 to 59 was considered as an index of an established dimension; finally, a t-score higher than 60 was considered as an index of a well-developed and organized dimension. At the end of the activity Chiara was given a report based on this analysis and describing her strengths.

\section{Results}

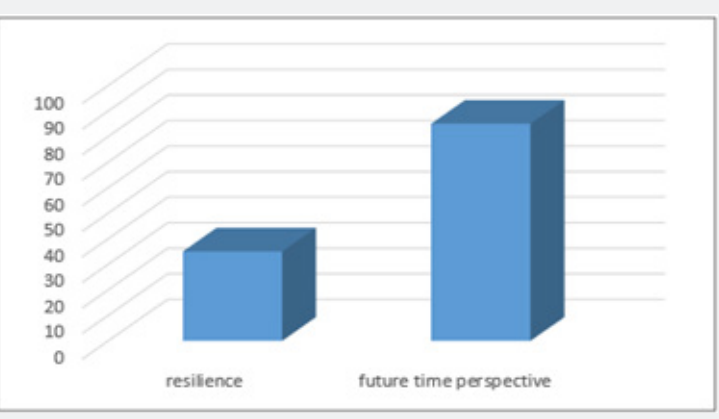

Figure 1: Levels of Resilience and Future Time Perspective that Chiara ascribed herself ( $\mathrm{t}$ scores). 


\section{Global Journal of Intellectual \& Developmental Disabilities}

Several strengths emerged from the analysis. As regards resilience and time perspective (Figure 1) Chiara seems to positively look at her future.

A closer look to the content of the items suggests that her future time perspective is characterized by hope, some ideas about the goals she wants to achieve but remaining open to new possibilities. Answers provided to the resilience scale suggest some vulnerability in her vision about her ability to face difficulties and obstacles that life presents to her, to take advantage of past experiences as a strength to start from.

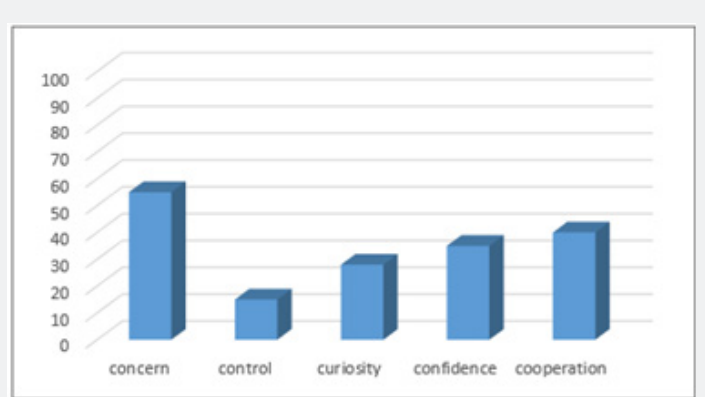

Figure 2: Levels of adaptability resources that Chiara ascribed herself (t scores).

As regards adaptability resources (Figure 2) she feels engaged in her future life (concern). Although she evidences a feeling of limited control on her future, in answers provided thinking about her future, caring about the future goals still characterize Chiara point of view; she reports confidence, although not strongly, in the possibility to reach her goals, to realize what lies ahead. There is evidence of some curiosity, some openness to diverse possibilities as well as a sense of cooperation with others.

Table 1: Chiara answers to questions referring to courage

Did you Happen to be Brave in your Life in the Past?

When I got stuck in the elevator and I was there for half an hour that stopped the elevator and there was no dad that was there. I was with Mom At home I was coming up. Last year or earlier ... I tried to stay calm. I was brave because I tried try to stay calm. I did not get angry.

\section{Will you Ever be Brave in your Life in the Future?}

Maybe if I decide to work in the hospital I will have to deal with a disabled patient, I'll have to pull him up, cheer him up, talk to him and tell him that you recover from that ... that is to be his assistant. What will you do? How to make the person in front of me feel good. How will the others behave? I hope so. I hope I will get good results.

\section{Do you know Someone who has been Brave?}

Filippo and Giovanni. Filippo needs so much courage because he is a child with a serious prematurity. Practically the sickness never passed, he was the only one of the three children to be saved. His parents and him need to be courageous.

When asked to describe actions or situations in which she experienced courage she produced adherent and detailed descriptions of her experiences, some of which are reported below (Table 1).
When asked about future goals and work activities she can foresee for herself, besides goals related to her health and family wellbeing, Chiara expresses an interest in working with children, in working in contexts where she can meet persons. She likes to have people around. This, in fact, can also make supports from others available which she believes are relevant to overcome the limits she experiences and the barriers she seems aware of, especially when she needs to "stay on a task for a long time"

\section{Discussion}

One of the aims of our work with Chiara was to identify her strengths, goals and wishes for the future. The activity in which she was involved helped her reflect on herself and her own characteristics. Her attitudes towards the future emerge as mainly positive. Although not well aware of what awaits her, she clearly defines goals for her future and showed she can deal with decisions to be taken with some sense of responsibility and hope.

Chiara proved to be able to reflect and think about what happens to her, to analyse situations and the possibility of realizing something in her future. She has a sense of difficulty and this leads her to have a more realistic view of her life. She shows some awareness of her limitations, but despite them she is not discouraged and does not give up.

Transitioning from adolescence to adulthood is a complex process. Adolescents living with intellectual disability are particularly vulnerable to difficulties in adjusting to changing environments and responsibilities, learning independent living and self-advocacy skills to successfully transition to a level of appropriate independence. From the assessment several strong resources emerged that can help Chiara face daily challenges and think about her future with a certain positivity. But some suggestions clearly emerge about dimensions to take care of, to put at the core of specific counselling actions, such as control, curiosity and confidence, to make her future goals achievable.

\section{Conclusion}

There is no doubt that professionals interested in social and work inclusion of people with disabilities are required a complex task in the assessment of attitudes and resources which literature evidence may play a significant role in future life designing. But in order to increase the probability for most vulnerable people to participate in social and working contexts and experience work and life satisfaction, professionals are required commitment and effort to search for these strengths. They are then required to emphasise their uniqueness and strengths, their positive characteristics, rather than place a massive attention to their vulnerabilities and disabilities to focus on and work to enhance resources and strengths. What Chiara shows is that assessing these resources is possible, that giving her voice was important to know the pattern of relative cognitive and behavioural strengths and awareness of needs. Assessing these attitudes and resources is then a step toward equipping them in developing a satisfactory life designing. 


\section{We Like to End Our Analysis Reporting Again Chiara's Own Words:}

"Sono una ragazza molto molto forte e determinata, soprattutto quando qualcosa mi interessa particolarmente. Se non raggiungo i miei obiettivi, ci sto male. Spesso penso con la mia testa e non do ascolto ai consigli altrui. Dovrei cercare di controllarmi."

[I am a very very strong and determined girl, especially when something particularly interests me. If I don't reach my goals, I feel upset. I often think with my head and don't listen to the advice of others. I should try to control myself].

\section{References}

1. Ferrari L, Sgaramella TM, Soresi S (2015) Bridging disability and work: Contribution and challenges of life design. Handbook of life design: From practice to theory and from theory to practice, Hogrefe, Gottingen, pp. 219-232.

2. Koerner MM (2014) Courage as identity work: Accounts of workplace courage. Academy of Management Journal 57(1): 63-93.

3. Savickas ML, Nota L, Rossier J, Dauwalder JP, Duarte ME et al. (2009) Life designing: A paradigm for career construction in the 21st century. Journal of vocational behaviour 75(3): 239-250.

4. Silverman AM, Verrall AM, Alschuler KN, Smith AE, Ehde DM (2017) Bouncing back again, and again: a qualitative study of resilience in people with multiple sclerosis. Disabil Rehabil 39(1): 14-22.

5. Ganguly R, Brownlow C, Du Preez J, Graham C (2015) Resilience thriving in post-secondary students with disabilities: an exploratory study. Research Reports of the National Center for Student Equity in Higher Education. Curtin University, Perth, Australia.

6. Dvorsky MR, Langberg JM (2016) A review of factors that promote resilience in youth with ADHD and ADHD symptoms. Clin Child Fam Psychol Rev 19(4): 368-391.

7. Battalio SL, Silverman AM, Ehde DM, Amtmann D, Edwards KA, et al. (2017) Resilience and function in adults with physical disabilities: an observational study. Arch Phys Med Rehabil 98(6): 1158-1164.

8. Sgaramella TM (2014) Life designing with intellectual disability: domain-specific goals and determinants in adolescents and young adults with intellectual disabilities. Journal of Intellectual Disability Research 52: 689-689.

9. Lindstrom L, Kahn LG, Lindsey H (2013) Navigating the early career years: Barriers and strategies for young adults with disabilities. Journal of Vocational Rehabilitation 39(1): 1-12.

10. Ochs LA, Roessler RT (2001) Students with disabilities: How ready are they for the $21^{\text {st }}$ century? Rehabilitation Counseling Bulletin 44(3): 170-176.

11. Holwerda A, Brouwer S, de Boer MR, GroothoffJ W, van der Klink JJ (2015) Expectations from different perspectives on future work outcome of young adults with intellectual and developmental disabilities. J Occup Rehabil 25(1): 96-104.

12. Sheftel A, Lindstrom L, Mc Whirter B (2014) Motivational enhancement career intervention for youth with disabilities. Advances in School Mental Health Promotion 7(4): 208-224.

13. WHO (2011) World report on disability Geneva: WHO, 350.

14. Ferrari L, Sgaramella TM, Santilli S, Di Maggio I (2017) Career adaptability and career resilience: The roadmap to work inclusion for individuals experiencing disability. In Psychology of Career Adaptability, Employability and Resilience. Springer, Cham, pp. 415431.

15. Hartung PJ (2015) The career construction interview. In Career Assessment Sense Publishers, Rotterdam, pp. 115-121.

16. Bivona U, Ciurli P, Barba C, Onder G, Azicnuda E, et al. (2008) Executive function and metacognitive self-awareness after severe traumatic brain injury. J Int Neuropsychol Soc 14(5): 862-868.

17. Soresi S, Nota L (2007) ASTRID-OR, Portfolio per l'Assessment, il Trattamento e l'Integrazione delle disabilità [Portfolio for the assessment, treatment and inclusion]. Giunti-Organizzazioni Speciali, Firenze.

18. Santilli S, Ginevra MC, Sgaramella TM, Nota L, Ferrari L (2017) Design my future: An instrument to assess future orientation and resilience. Journal of Career Assessment 25(2): 281-295.

19. Nye CD, Leong F, Prasad J, Gardner D, Tien HLS (2018) Examining the Structure of the Career Adapt-Abilities Scale: The Cooperation Dimension and a Five-Factor Model. Journal of Career Assessment 26(3): 549-562.

\section{Your next submission with Juniper Publishers will reach you the below assets}

- Quality Editorial service

- Swift Peer Review

- Reprints availability

- E-prints Service

- Manuscript Podcast for convenient understanding

- Global attainment for your research

- Manuscript accessibility in different formats

( Pdf, E-pub, Full Text, Audio)

- Unceasing customer service

Track the below URL for one-step submission https://juniperpublishers.com/online-submission.php 